\title{
AKAD QORDHUL HASAN SEBAGAI SETRATEGI BAZNAS JATIM DALAM MENGOPTIMALISASIKAN DANA ZAKAT UNTUK PEMBERDAYAAN UMMAT
}

\author{
Moh. Munir \\ Asrori \\ e-mail:munirkarah@gmail.com
}

\begin{abstract}
The formulation of the research problem in this thesis can be described as follows: First, How is the strategy of Baznas East Java in optimizing the zakat fund, second, How is the implementation of Qordhul Hasan in Baznas East Java, the third is the qordhul Hasan agreement in accordance with the fatwa Number: 19 / DSNMUI / IV / 2001.

This qualitative research approach is research using explorative research method and descriptive research method. Data collection method is by interview with snowball technique, observation, documentation and literature study through several book and internet sources, hence the result of research finding of Baznas East Java in optimizing zakat fund there are five programs that is East Java Smart, East Java Healthy, East Java Devotion, East Java is prosperous and East Java cares. The empowerment of zakat makes the mustahik have the power of the development of resources of the community in the form of creativity, competence and thinking power considering the economic growth and technology so rapidly will greatly affect the ability of each individual in fulfilling the needs of his life then with prosperous Java Baznas program includes the aid of work tools, work in collaboration with BLK and Cooperation services provide the skills of UMKM and revolving capital assistance that partner with or work together with mosque board, Reading Qur'an community and county Baznas who know the condition of the mustahik by making a letter of application and ready to be surveyed to pilgrims who will get capital assistance. The procedure is that the aid will be handed over to the mosque administrator, reading Qur'an community and the county Baznas for the next of the same committee is handed over to mustahik who is well worthy of receiving assistance.

The result of the research showed that Eat Java Baznas is in accordance with the fatwa Number: 19 / DSN-MUI / IV / 2001 which reads "That one of the means of economic improvement that can be done by LKS / BAZNAS is channeling funds through Al-Qordh principle, to the customer or mustahik provided that the client I mustahik is obliged to return the funds received in accordance with the agreement. If the Client / Mustahik cannot refund part or all of his liability for his / her inability then may extend the repayment period or partially off or off his / her liabilities.
\end{abstract}

Keywords: Qordhul Hasan Agreement, Strategy, Optimize, Zakat Empowerment

PENDAHULUAN 
Zakat menjadi sebuah sistem perekonomian yang harus diterapkan dalam upaya pemberdayaan perekonomian umat $^{1}$. Dengan jumlah pemeluk Islam terbanyak, maka potensi zakat sebagai gerakan alternatif bagi pengentasan kemiskinan dapat segera diwujudkan. Zakat tidak hanya ibadah Mahdoh, melainkan sebagai ibadah yang berkaitan erat dengan ekonomi, keuangan dan kemasyarakatan.

Harta itu harus dikembangkan dalam bentuknya yang beragam. Harta zakat ( utamanya zakat mal ) harus dipandang sebagai modal dana berputar ( revolving fund) yang penggunaanya harus diarahkan kepada usaha produktif dan dikembangkan sehingga mampu menciptakan keseimbangan ekonomi. Dengan demikian, zakat menjadi sebuah sistem perekonomian yang harus diterapkan dalam upaya pemberdayaan perekonomian ummat.

Dari program Baznas jawa timur diantaranya adalah Bantuan modal bergulir, memberikan pinjaman untuk tambahan modal bagi UMKM yang usahanya telah berjalan. Modal bergulir dengan QARDHUL HASAN bantuan modal diberikan bagi UKM yang sudah beroperasi.

\section{PEMBAHASAN}

\section{Pengertian Qordhul Hasan}

Dalam hukum Islam tidak pernah ada anjuran melakukan aktifitas bisnis dengan cara utang, tetapi tampaknya sudah menjadi tren saat ini, utang selalu asesor denga bisnis. Bahkan sudah mulai terkuak ke permukaan suatu sinylemen dalam urusan bisnis bahwa pebisnis yang berani berutang dialah yang berpeluang. Sementara kegiatan usaha bank pada umumnya memberikan dana dengan akad pinjaman (kridit/qord/utang) dengan pengembalian pakai bunga ${ }^{2}$. Dalam usaha pembiayaan, bank syariah mempunyai lima jenis transaksi yaitu :

1. Transaksi bagi hasil dalam bentuk mudharabah dan musyarakah.

2. Transaksi sewa menyewa dalam bentuk ijarah atau ijarah bi mumtahia bittamlik (IMB).

3. Transaksi jual beli dalam bentuk salam, istisna dan murabahah.

4. Transaksi pinjaman dalam bentuk qard

5. Transaksi sewa menyewa jasa ijarah untuk transaksi multi jasa.

Menurut istilah berarti meminjamkan uang kepada orang dengan tidak mengambil manfaat apapun dari pinjamannya itu. Sedangkan menurut Muhammad Syafii Antonio, qard adalah meminjamkan tanpa mengharapkan imbalan. Qard adalah pemberian harta kepada orang lain yang dapat ditagih atau diminta kembali tanpa mengharapkan imbalan atau dengan kata lain merupakan sebuah transaksi pinjam meminjam tanpa syarat tambahan pada saat pengembalian pinjaman. Dalam literatur

${ }^{1}$ Kementrian agama RI direktorat jenderal bimbingan masyarakat islam, direktorat pemberdayaan zakat, panduan pengembangan usaha bagi mustahik. (digandakan oleh kantor wilayah kementerian agama provinsi jawa timur tahun jawa timur), 28

${ }^{2}$ Jeni Susanti, pengolahan keuangan syariah ( Malang=referensi 2016),31 
fiqh klasik, qordh dikategorikan dalam aqad tathawwui atau akad tolong menolong dan bukan transaksi komersial.

Dana qordhul hasan dapat bersumber dari dana zakat, infaq, shodaqah dan wakaf yang dipisahkan untuk pengembangan usaha produktif bagi fakir miskin secara professional. Melalui skema qordhul hasan, para penerima dana dilatih untuk bertanggung jawab terhadap dana yang diterimanya dan harus dapat menjadikan taraf hidupnya meningkat dari saat sebelum yang bersangkutan menerima dana qordhul hasan. Qordhul hasan yang menghasilkan manfaat diharamkan jika diisyaratkan.Pada dasarnya, prinsip qordhul hasan sama dengan qordh, yaitu saling menolong. Namun yang membedakan keduanya adalah sumber dana. Dalam qordhul Hasan, sumber dana yang dipinjamkan bersumber dari dana ZIS, sedangkan Qordh bersumber dari dana modal BMT atau laba yang disisihkan

\section{Dasar Hukum Qordhul Hasan.}

Hukum qordh itu mubah (boleh) yang didasarkan prinsip tolong menolong.

Berikut ini dasar hukumnya :

1. Al-qur'an

a. Surat al-baqarah (2) ayat 245 :

من ذالذي يقرض قرضاحسنا فيضعفه له اضعافا كثير ة والله يقبض ويیصط و اليه ترجعو ن

Artinya : "Siapakah yang mau memberi pinjaman kepada Allah, pinjaman yang baik baik ( Qordhul Hasan ), maka Allah melipatgandakan pembayarannya ". 3

b. Surat al-hadid (57) ayat 11 :

$$
\text { من ذالذي شقرض الله قرضا حسنا فيضعفه له وله اجر كريم }
$$

Artinya : "Barangsiapa yang meminjamkan kepada Allah dengan pinjaman yang baik, maka Allah akan mengembalikannya berlipat ganda untuknya, dan baginya pahala yang mulia “.

Artinya : " Orang yang terbaik diantara kamu adalah orang yang paling baik dalam pembayaran utangnya ". ( HR. Bukhori )

2. Kaidah usul fiqih Artinya : "Hukum asal dari sesuatu (muammalah) adalah mubah sampai ada dalil yang melarangnya.

Fatwa Dewan Syariah Nasional Nomor : 19/DSN-MUI/IV/2001 tentang AlQord memutuskan ketentuan umum al-qord :

1. Al-qordh adalah pinjaman yang diberikan kepada nasabah (muqtaridh) yang memerlukan .

2. Nasabah al-qordh wajib mengembalikan jumlah pokok yang diterima pada waktu yang telah disepakati bersama.

3. Biaya admnistrasi dibebankan kepada nasabah.

Setrategi Baznas Jatim dalam mengoptimalisasikan dana zakat dengan cara bekerja sama dengan Baznas Daerah, Masjid dan Komunitas pengajian. Kehadiran Baznas daerah, Masjid dan komunitas pengajian yang tahu kondisi daerah dan kondisi jamaahnya, Zakat menjadi perhatian kita disini adalah pola pemberdayaan

\footnotetext{
${ }^{3}$ Alqur,an terjemahan kementerian agama RI
} 
zakat sebagai bagian dari upaya pengentasan kemiskinan. Pola pemberdayaan zakat sendiri berada dalam dua katagori yaitu :

1. Pola konsumtif.

2. Pola Produktif

\section{Pelaksanaan qordhul hasan yang ada di Baznas Jatim.}

Pelaksanaan Qordhul Hasan yang ada di Baznas Jatim bekerja sama dengan Basnas Daerah, Masjid dan komunitas pengajian yang mengetahui kondisi jamaahnya untuk diberikan bantuan modal bergulir atau bantuan modal usaha pada tahun 2014 jumlah mustahik 98 orang dengan total pembayaran Rp. 648.210.000, pada tahun 2015 jumlah mustahik 75 dengan total pembayaran Rp. 120.600, pada tahun 2016 jumlah mustahik 46 dengan total pembayaran Rp. 67.000.000, dan pada tahun 2017 jumlah mustahik 49 dengan total pembayaran Rp. 49.000.000.

4. Apakah qordhul Hasan tersebut sudah sesuai dengan fatwa Nomor 19/DSNMUI/IV/2001

Berdasarkan fatwa dewan syariah nasional tanggal 24 Muharram 1422H bertepatan 18 april 2001 menyatakan bahwa lembaga keuangan syariah atau ( LKS ) disamping sebagai lembaga komersial, harus dapat berperan sebagai lembaga social yang dapat meningkatkan perekonomian secara maksimal, bahwa salah satu sarana peningkatan perekonomian yang dapat di lakukan oleh LKS adalah penyaluran dana melalui prinsip qordhul Hasan, yaitu suatu akad pinjaman kepada nasabah atau mustahiq dengan ketentuan bahwa nasabah atau mustahiq wajib mengembalikan dana yang diterimanya kepada LKS pada waktu yang telah disepakati oleh LKS dan nasabah atau mustahiq, agar akad tersebut sesuai dengan syariat islam.

\section{KESIMPULAN}

Berdasarkan paparan dan analisis yang telah diuraikan di atas dapat di simpulkan beberapa hal sebagai berikut:

1. Baznas jawa timur dibentuk oleh menteri atas usul gubernur setelah mendapat pertimbangan baznas pusat, untuk melaksanakan pengelolaan zakat di wilayah jawa timur.

2. Baznas jatim untuk memberdayakan zakat menggunakan 2 kategori yaitu:

1) Konsumtif adalah menjadi kebutuhan dasar atau kebutuhan pokok yang telah di amanatkan oleh undang-undang nomor 14 tahun 2011 pasal 27 ayat

2) Produktif adalah merubah polah hidup dengan memberikan dengan latihan keterampilan, modal kerja, bantuan pendirian gerai-gerai atau outlet yang telah di amanatkan oleh undang-undang nomor 14 tahun 2011 pasal 27 ayat

3. Saya sebagai muzaqqi yang menyerahkan zakat ke Baznas jatim setiap bulan sangat bahagia bahwa distribusi zakat bisa di kembangkan untuk perberdayaan ekonnomi ummat

\section{DAFTAR PUSTAKA}


Abdul. Hadi, Memahamiakad-akaddalamperbankansyariahdandasar dasarhukumnya, (Surabaya: SinarTerang, 2015)

Abdullah abdul Hasan At Tariqi, Ekonomi ISlam Prinsip Dasar dan Tujuan, (Yogyakarta: Magistra Insane Press, 2004)

Aziz Dahlan Abdul, Enkslopedi Hukum Islam, (Jakarta: PT Ichtiar Baru Vanvove, 1997)

A Rahman Ritonga dan Zainuddin, Fiqh Ibadah, (Jakarta: Gaya Media Pratama, 2002)

A Djazuli, Lembaga-lemaga Perekonomian umat, sebuah pengantar, (Jakarta, Rajawali Grafindo Persada, 2002)

Ditjen Bimas Islam dan Penyelengharaan Ibadah Haji, Realitas \& Tantangan Penyelenggaraan Ibadah Haji, (Jakarta: Ditjen BPIH, 2003)

Fadhul ,Fikih abdullah Ibnu Mas'ud ra. fi Fiqh'il Muamalat, Diraasah

Gufron A. Mas'adi, FiqhMuamalahKonsektual, (Jakarta: Raja Grafindo Persada, 2002)

Gunawan Imam, Metode Penelitian Kualitatif Teori Dan Praktik, (Jakarta: Bumi Aksara, 2016)

Wahbah Alzuayly, Zakat Kajian Berbagai Mazhab ( Bandung: PT, Remaja Rosda Karya, 2008)

Jeni Susyanti, Pengelolaan Lembaga Keuangan Syariah ( Malang: 42, 2016)

M. Hasan Ali ,Berbagai macam Transaksi dalam Islam (Fiqh Mu'amalat) (Jakarta: Rajawali Pres, 2003)

Muaqarranah (Saudi Arabia, Ummul Qura, Perss, 2004),

Nurul Huda,Purnama Putra, Novarini, yosi Mardoni, Baitul Mall Wa Tamwil sebuah tinjauan teoritis (Jakarta: Amzah,2016)

Akhmad Mujahidin, Hukum Perbankan Syariah ( Jakarta:Pt Raja Grafindo Persada, 2016)

Iqbal M .Aris Ali, Kekuatan Entitas Syariah Yang Terlupakan (Jakarta:Pt Raja Grafindo Persada, 2016)

Kantor Wilayah Kementerian Agama Provinsi Jatim, Fiqh Zakat ( Surabaya, 2004)

Direktotat Jenderal Bimbingan Masyarakat Islam, Direktorat Pemberdayaan zakat, ( Jakarta,2012)

Direktotat Jenderal Bimbingan Masyarakat Panduan Pengembangan Usaha bagi Mustahiq ( Jakarta,2009)

Direktotat Jenderal Bimbingan Masyarakat, Panduan Organisasi Pengelola Zakat ( Jakarta,2010)

Proyek Pembinaan Zakat dan Wakaf, Pedoman Zakat 9 Seri ( Jakarta: 1985/1986)

Direktotat Jenderal Bimbingan Masyarakat Islam,Direktotat Jenderal Pemberdayaan Zakat ( Jakarta: 2012 )

Himpunan Peraturan Perundang-Undangan Republik Indonesia, Undang-Undang Pengelolaan Zakat nomor 23 Tahun 2011 ( Jogjakarta: 2011)

M.Ma'ruf Abdullah, Hukum Keuangan Syariah Pada Lembaga keuangan bank dan Non Bank (Jogjakarta: Aswaja Pressindo,2016) 
Direktotat Jenderal Bimbingan Masyarakat Islam, Direktorak Pemberdayaan zakat, Standar Operasional Prosedur Lembaga Pengellolaan Zakat,( Jakarta:2011)

Mukhtar, Metode Praktis Penelitian Deskriptif Kualitatif, (Jakarta: Referensi, 2013)

Nazir Habib dan Muhammad Hasanuddin, Ensiklopedi Ekonomi dan Perbankan Syariah, (Bandung: Kafa Publising, 2008)

Sjahdeini, Perbankan Islam dan Kedudukannya Dalam Tata Hukum Perbankan Indonesia, (Jakarta: Pustaka Utama Grafiti, 1999).

Soemitra Andri, Bank dan Lembaga Keuangan Syariah, (Jakarta: Kencana, 2009),

Sumitro Warkum, Asas-asas Perbankan Islam dan Lembaga-lembaga terkait BMUI dan Tafaku, (Jakarta: PT Raja Grafindo, 1996)

Sutedi Andrian, Perbankan syariah: Tinjauan dan Beberapa segi hukum, (Jakarta: Ghalia Indonesia, 2009,)Soerjono Soekanto dan Sri Mamudji, Penelitian Hukum Normatif, (Jakarta: PT Grafindo persada, 2006)

Sugiono, Metode Penelitian Kuantitatif, Kualitatif dan $R \& D$ (Bandung: Alfabeta, 2014)

Prastowo Andi, Metode Penelitian Kualitatif dalam Perspektif Rancangan Penelitian, ( Jogjakarta: Ar-rum Media, 2014) 